\title{
Cellular Composition Changes and Nitrogen Uptake under Extra-Limited Nitrogen Conditions by Thermosynechococcus sp. CL-1 Carbon Biofixation
}

\author{
Tseng Chi-Ming, ${ }^{1}$ Ko Tzu-Hsing, ${ }^{2}$ Hsueh Hsin-Ta, ${ }^{3}$ \\ Chen Hsing-Hui, ${ }^{4}$ Ray Dah-Tong, ${ }^{1}$ Shen Yun-Hwei, ${ }^{1}$ and Chu Hsin ${ }^{4}$ \\ ${ }^{1}$ Department of Resources Engineering, National Cheng Kung University, Tainan, Taiwan \\ ${ }^{2}$ Department of Tea Science, Anxi College of Tea Science, Fujian Agricultural and Forestry University, Fuzhou 350002, China \\ ${ }^{3}$ Sustainable Environment Research Laboratories, National Cheng Kung University, Tainan, Taiwan \\ ${ }^{4}$ Department of Environmental Engineering, National Cheng Kung University, Tainan, Taiwan
}

Correspondence should be addressed to Hsueh Hsin-Ta; adathen@mail.ncku.edu.tw and Chu Hsin; chuhsin@mail.ncku.edu.tw

Received 26 May 2016; Accepted 7 August 2016

Academic Editor: Zoran Vujcic

Copyright (C) 2016 Tseng Chi-Ming et al. This is an open access article distributed under the Creative Commons Attribution License, which permits unrestricted use, distribution, and reproduction in any medium, provided the original work is properly cited.

\begin{abstract}
Two types of culture systems were used (continuous and batch) which were fed using a simulated absorbent from a scrubber with carbonate/bicarbonate as the carbon source and nitrate as the nitrogen source by a thermophile strain, Thermosynechococcus sp. CL-1 (TCL-1) at $50^{\circ} \mathrm{C}$. The lipid, carbohydrate, and protein cellular components which can be used as bioenergy precursors along with their content as a function of various $\mathrm{C} / \mathrm{N}$ ratios are quantified. Maximum lipid productivity of about $150 \mathrm{mg} \mathrm{L}^{-1} \mathrm{~d}^{-1}$ is obtained while the $\mathrm{CO}_{2}$ uptake rate is $917 \mathrm{mg} \mathrm{L}^{-1} \mathrm{~d}^{-1}$ at a dilution rate of $0.06 \mathrm{~h}^{-1}$ when both carbon and nitrogen sources are not limited. With high range of nitrogen concentrations batch culture test, TCL-1 reveals extra-high affinity on nitrogen source under limited carbon source conditions since the affinity constant is $0.12 \mathrm{mM}$. In addition, the flow of carbon fixed during photosynthesis seems to switch from the protein synthesis pathway to forming carbohydrate rather than lipid under $\mathrm{N}$-limitation and a high $\mathrm{C} / \mathrm{N}$ ratio for TCL-1, resulting in a maximal carbohydrate content of $61 \%$. Consequently, TCL- 1 is an appropriate candidate to treat the wastewater of environment and produce the bioenergy precursors under extreme limited nitrogen conditions.
\end{abstract}

\section{Introduction}

The Kyoto protocol was based on the aim of reducing greenhouse gas emissions, especially at lowering the amount of carbon dioxide released. Further, the UN Climate Summit (COP21) was held on December of 2015 in Paris, France. 195 countries participated and voted unanimously to achieve the "Paris agreement." All of the countries involved were required to reduce greenhouse gas emissions following the content of the agreement. Another critical worldwide question is how to solve food and energy shortages. There is a potential to produce food/pharmaceutical products or bioenergy when assimilating $\mathrm{CO}_{2}$ with photosynthetic microorganisms. For carbon biofixation with photosynthetic microorganisms, a thermophile strain, Thermosynechococcus sp. CL-1 (TCL-1), in which dissolved inorganic carbon (DIC) was added to simulate a high concentration of carbon source derived from washing hot flue gas, was also used for practical application in an integrated system of $\mathrm{CO}_{2}$ absorption in an alkaline absorber and also for biological fixation of DIC in a photobioreactor in a batch culture $[1,2]$. Additionally, the carbohydrate content as a function of DIC concentrations without an N-limitation has also been found in the same batch culture [1]. In general, a batch culture is easier than a continuous culture in regard to operation. However, the cultivation conditions in batch cultures are always changing, resulting in possible variations in the cellular composition. Since information regarding the continuous cultivation with DIC feeding is limited and continuous operation can provide stable cellular component production under given conditions, it is of interest to find the performance of carbon biofixation and the productivity of 
lipids and carbohydrates with TCL-1 in a continuous culture for the purpose of practical applications. On the other hand, the productivity of biomass (or its cellular components) can be obtained on the basis of good cultivation conditions $[3,4]$. Several reports focused on the production of polyunsaturated fatty acids from microalgae have been addressed [5-8]. For bioenergy subject, photosynthetic microorganisms partially composed of lipids and carbohydrates are valuable as the precursors of biodiesel and bioethanol. Therefore, higher lipid and carbohydrate content or productivity are important in the cultivation of photosynthetic microorganisms $[9,10]$. Consequently, the production of biodiesel or bioethanol goal precursors under a specific condition in a continuous culture is important.

From the semiquantitative analysis with Fourier Transform Infrared Spectroscopy (FTIR), it was observed that the lipid production pathway shifted to carbohydrate from 18.9 to $47.2 \mathrm{mM}$ of DIC, and the carbohydrate content increased quickly from 47.2 to $94.3 \mathrm{mM}$ without a further decrease in lipid [11]. In addition, a quantitative analysis of cellular components of TCL-1 cultivated in a batch culture was conducted. Results found that carbohydrate or lipid content was also a function of DIC concentrations. Therefore, it is also of interest to find the variations in the carbohydrate or lipid content and survey the productivity of this species under various concentrations of DIC without $\mathrm{N}$-limitation in a continuous culture [1].

In addition to the effect of DIC concentrations, the content of cellular components, lipids, carbohydrates, and so on can be changed significantly when nutrients are limited, especially nitrogen [12-14]. It is clear that the cellular components are dependent on microbial species and that the distribution between lipid and carbohydrates contents is different even under the identical N-limiting conditions for different species. Consequently, microalgae are used widely to treat not only gaseous effluents but also wastewater components by various species [15]. In this study, the content and productivity of the cellular components of TCL-1 in a batch and continuous culture, including lipids, carbohydrates, and proteins, were quantified as a function of initial dissolved inorganic nitrogen (DIN) (nitrate) concentrations and initial DIC concentrations.

\section{Materials and Methods}

2.1. Microbial Species. The TCL-1 strain was isolated from the Chin-Lun hot spring $\left(\mathrm{pH} 9.3,62^{\circ} \mathrm{C}\right)$ in Taiwan, as described previously [11]. A modified Fitzgerald medium was adopted as the growth culture consisting of (in mg L$\left.{ }^{-1}\right) 496 \mathrm{NaNO}_{3}$, $39 \mathrm{~K}_{2} \mathrm{HPO}_{4}, 75 \mathrm{MgSO}_{4} \cdot 7 \mathrm{H}_{2} \mathrm{O}, 27 \mathrm{CaCl}_{2}, 58 \mathrm{Na}_{2} \mathrm{SiO}_{3}, 6$ $\mathrm{FeC}_{6} \mathrm{H}_{5} \mathrm{O}_{7}, 6$ citric acid, and 1 EDTA and $1 \mathrm{~mL} \mathrm{~L}^{-1}$ Caffron solution in distilled water [16].

2.2. Growth Conditions. The cultivation was carried out at $50^{\circ} \mathrm{C}$ in an illuminated incubator (FH-130w) at initial $\mathrm{pH}$ of 9.5 but without a control during the cultivation period. The turbulence of the cultivation solutions was controlled by a magnetic stirrer at a constant speed to enhance the mixing of the bioreactor content, thus avoiding settling of the biomass. The illumination intensity was determined at the nearest distance from the light source to the surface of the bioreactor using a Lux meter (TM 50000, TOMEI). The DIC source was prepared with a mixture of $\mathrm{NaHCO}_{3}$ and $\mathrm{Na}_{2} \mathrm{CO}_{3}$ while the DIN was prepared with $\mathrm{NaNO}_{3}$. Initial $\mathrm{OD}_{680 \mathrm{~nm}}$ in the bioreactor was controlled at about 0.2 prepared with the mixture of cells from the activation cultivation and a given volume of fresh medium in each run.

In the continuous culture, the bioreactor used was a bubble column with a height of $400 \mathrm{~mm}$, an I.D. of $69 \mathrm{~mm}$, an O.D. of $70 \mathrm{~mm}$, and a working volume of $1 \mathrm{~L}$. Additionally, $50 \mathrm{~mL} \mathrm{~min}^{-1}$ of $\mathrm{N}_{2}$ was bubbled into the bioreactor to avoid the accumulation of oxygen via photosynthesis. The experimental scheme is shown in Figure 1 . The effect of the various feeding DIC concentrations ranged from 28 to $113 \mathrm{mM}$ at a $5.8 \mathrm{mM}$ DIN concentration and a $0.036 \mathrm{~h}^{-1}$ dilution rate.

In the batch culture, the bioreactor used was a bubble column with a height of $176 \mathrm{~mm}$, I.D. of $84 \mathrm{~mm}$, an O.D. of $86 \mathrm{~mm}$, and a working volume of $0.5 \mathrm{~L}$. The cultivation was carried out at $10 \mathrm{klx}$ illumination intensity while the initial DIN concentration was either 28 or $47 \mathrm{mM}$. The initial DIN concentrations were controlled in a range of 0.2 to $5.8 \mathrm{mM}$.

2.3. Analyses. $\mathrm{OD}_{680 \mathrm{~nm}}$ was measured with a UV-visible spectrophotometer (Lambda 35, Perkin Elmer, USA) about twice a day, and $\mathrm{pH}$ was measured at the same frequency. Cell mass was obtained by the measurement of the dry weight of the filter $(0.45 \mu \mathrm{m})$ before and after $105^{\circ} \mathrm{C}$ upon filtering a given amount of the culture content, and the correlation between optical densities and cell mass was derived.

The algal cells in the solution were collected with a centrifuge (U-32R, BOECO, Germany) operating at 6,000 rpm for $15 \mathrm{~min}$, and the same procedure was repeated three times with the addition of distilled water. The cell obtained was eventually dried in a vacuum freeze-dryer (FDU-1200, EYELA, Japan) for subsequent measurements of cellular components.

The lipid content of the algal cells was estimated from the extract by the gravimetric analyses, with the extraction solution of methanol/chloroform (1:2) [17]. The extraction efficiency was enhanced by supersonic vibration for $5 \mathrm{~min}$, and the supernatant was collected using centrifuge for $10 \mathrm{~min}$ at $3,000 \mathrm{~g} .1 \mathrm{~N}$ of $\mathrm{NaOH}$ was added to the lipid-free pellet and heated $10 \mathrm{~min}$ in boiling-water to dissolve the pellet for the determination of carbohydrate and protein content. The carbohydrate analytical method was followed by the colorimetric method at $485 \mathrm{~nm}$ [18]. The determination of proteins followed a well-known dye binding method at $595 \mathrm{~nm}[19]$.

\section{Results and Discussion}

3.1. Continuous Cultivation under Various Feeding DIC Concentrations. Since information regarding continuous cultivation with DIC feeding is limited and continuous operation can provide stable cellular component productions under any given conditions, it is of interest to find the performance of 


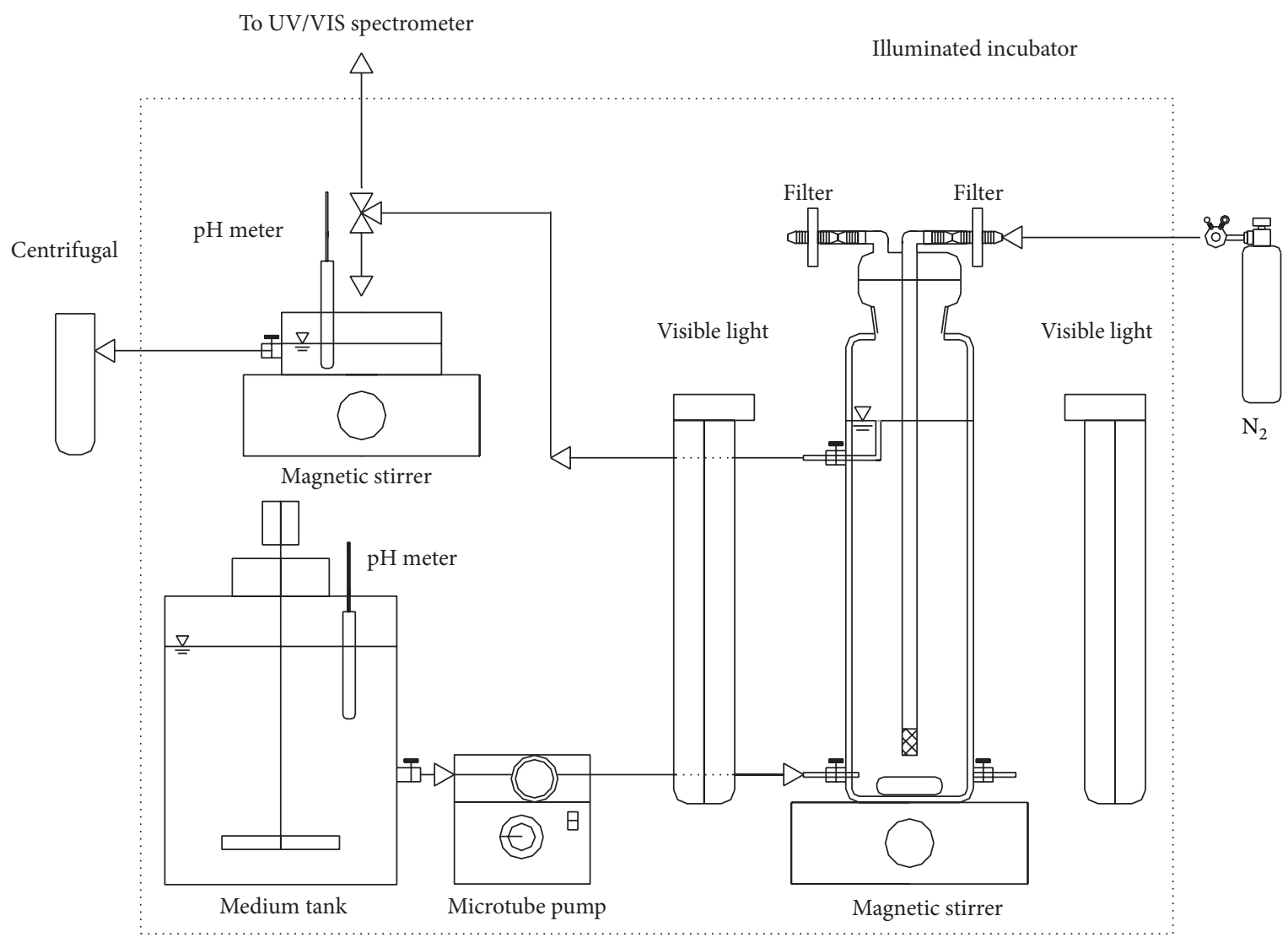

FIGURE 1: Experimental scheme of continuous cultivation in this study.

carbon biofixation with TCL-1 in a continuous culture for practical applications.

As shown in Table 1, the cell mass in the steady state is a function of the feeding DIC concentration. According to these data, the cell mass productivity in the steady state increases from 259 to $657 \mathrm{mg} \mathrm{L}^{-1} \mathrm{~d}^{-1}$ as the feeding DIC concentration increases from 28 to $85 \mathrm{mM}$ while DIN is $5.8 \mathrm{mM}$ at a dilution rate of $0.036 \mathrm{~h}^{-1}$. The cell mass productivity at the feeding DIC concentration of $113 \mathrm{mM}$ is similar to that at $85 \mathrm{mM}$ and reflects the saturation of DIC under both conditions. It is noted that there is a $\mathrm{pH}$ variation in the medium ranges between 9.1 and 10.8 at the steady state of various cultivated conditions. According to a previous study, $\mathrm{pH}$ should not be a parameter affecting the growth of TCL-1 in this range [2].

In previous studies, the carbon content of TCL-1 cell was found to be about $40 \%[1,2,11]$. The carbon removal efficiency and carbon uptake rate can be estimated on the basis of this value. As shown in Table 1, the carbon removal efficiency decreases from 31 to $19 \%$ while the carbon

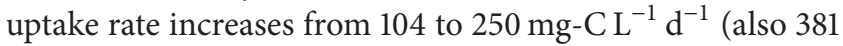
to $917 \mathrm{mg}-\mathrm{CO}_{2} \mathrm{~L}^{-1} \mathrm{~d}^{-1}$ ) as the feeding DIC concentration increases from 28 to $113 \mathrm{mM}$. In Taiwan, $\mathrm{CO}_{2}$ production from combustion in 2007 (268,881,000 tons) was investigated by Energy and Environment Research Laboratories, the Industrial Technology Research Institute of Taiwan. In the present study, we can apply our system to eliminate amounts of $\mathrm{CO}_{2}$ under ideal conditions and an adequate cultivated area. For example, on the basis of $900 \mathrm{mg}-\mathrm{CO}_{2} \mathrm{~L}^{-1} \mathrm{~d}^{-1}$, $98,550,000$ tons of $\mathrm{CO}_{2} \mathrm{yr}^{-1}$ can be biofixed and turned into biofuel precursors if $1,000 \mathrm{~km}^{2}$ of area $(2.8 \%$ of Taiwan land) and $30 \mathrm{~cm}$ of depth are provided. It was noted that the problem with respect to the heating cost rose due to our thermophile cyanobacterium. However, our idea with respect to DIC was obtained by scrubbing $\mathrm{CO}_{2}$ from "hot" flue gas, resulting in a lowered cost using heat recovery. Additionally, another group of processes for direct thermal conversion of biomass employs a liquid medium for conversion of biomass to liquid fuels.

In order to find the content of the cellular components as a function of various feeding DIC concentrations, a biomass sample is taken from the medium and analyzed at the steady state of every given feeding DIC concentration. As shown in Figure 2, the lipid content decreases from 28 to $19 \%$ as the feeding DIC concentrations increase from 28 to $113 \mathrm{mM}$, reflecting that a slight nitrogen limitation occurs as cultivation is operated under higher feeding DIC concentrations to most likely limit lipid-synthesizing enzymes. However, the cell mass in the steady state increases from 259 to $657 \mathrm{mg} \mathrm{L}^{-1} \mathrm{~d}^{-1}$ as the feeding DIC concentration increases from 28 to 85 or $113 \mathrm{mM}$. Consequently, the maximal lipid productivity of about $150 \mathrm{mg} \mathrm{L}^{-1} \mathrm{~d}^{-1}$ is obtained at the feeding DIC concentration of $85 \mathrm{mM}$ (Table 1). This productivity is at the same level as that of a semicontinuous culture 
TABLE 1: Cellular data for TCL-1 in a continuous culture at various feeding DIC concentrations.

\begin{tabular}{|c|c|c|c|c|c|}
\hline \multirow{2}{*}{$\begin{array}{l}\text { Feeding DIC } \\
\text { concentration }(\mathrm{mM})\end{array}$} & \multicolumn{4}{|c|}{$\begin{array}{l}\text { Cell or cellular component productivity }{ }^{*}, \mathrm{mg} \mathrm{L}^{-1} \mathrm{~d}^{-1} \text { (content, \%) } \\
\text { at the steady state }\end{array}$} & \multirow[t]{2}{*}{$\begin{array}{l}\text { Carbon remova } \\
\text { efficiency }^{\S}(\%)\end{array}$} \\
\hline & Cell & Lipid & Carbohydrate & Protein & \\
\hline 28 & 259 & $73(28.2 \pm 5)$ & $23(10.4 \pm 2.4)$ & $59(22.8 \pm 4.3)$ & 31 \\
\hline 57 & 501 & $142(28.3 \pm 6.7)$ & $125(25 \pm 1.2)$ & $162(32.3 \pm 10)$ & 29 \\
\hline 85 & 657 & $149(22.7 \pm 1.6)$ & $155(23.6 \pm 4.7)$ & $247(37.6 \pm 12.5)$ & 26 \\
\hline 113 & 639 & $123(19.3 \pm 2.6)$ & $153(24 \pm 1.3)$ & $238(37.2 \pm 9.7)$ & 19 \\
\hline
\end{tabular}

$0.036 \mathrm{~h}^{-1}$ of dilution rate, $5.8 \mathrm{mM}$ feeding DIN concentration, $50^{\circ} \mathrm{C}$ cultivation temperature, $10 \mathrm{klx}$ illumination intensity.

*Poductivity $\left(\mathrm{mg} \mathrm{L}^{-1} \mathrm{~d}^{-1}\right)=$ mass $\left(\mathrm{mg} \mathrm{L}^{-1}\right) *$ dilution rate $\left(\mathrm{h}^{-1}\right) * 24 \mathrm{~h} \mathrm{~d}^{-1}$.

${ }^{\S}$ Carbon removal efficiency $(\%)=[$ cell mass $* 0.4 /($ feeding DIC concentration $* 12)] * 100 \%$.

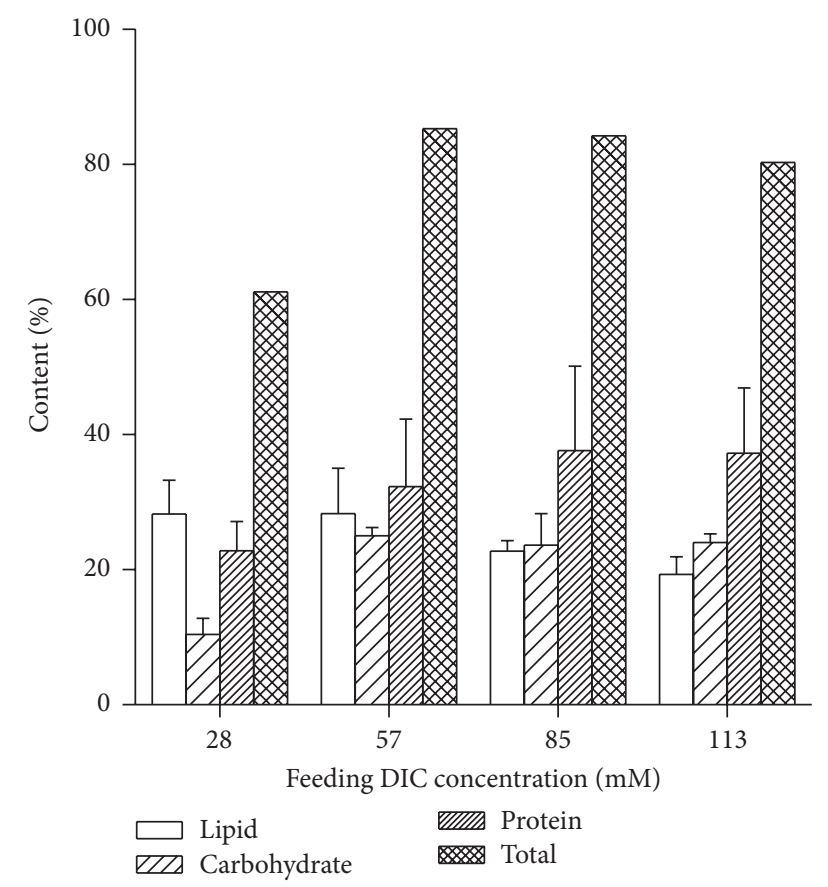

FIGURE 2: Cellular composition under various feeding DIC concentrations in a continuous culture.

under N-limitation using Chlorella sp. of $139 \mathrm{mg} \mathrm{d}^{-1} \mathrm{~L}^{-1}$ conducted by Hsieh and $\mathrm{Wu}$ [13]. In Taiwan, oil consumption in $2008,(45,525,700 \mathrm{~kL})$ was estimated by the Bureau of Energy, Ministry of Economic Affairs of Taiwan. We can apply our system to produce amounts of oil for fuels under ideal conditions and adequate cultivation area. For example, on the basis of $150 \mathrm{mg}$ oil L $\mathrm{d}^{-1}, 20,531,250 \mathrm{~kL}$ oil can be produced as biofuel if $1,000 \mathrm{~km}^{2}$ of area and $30 \mathrm{~cm}$ of depth are provided.

The carbohydrate content seems to be a function of the feeding DIC concentration, and the content increases from 10 to $25 \%$ as the concentration increases from 28 to $57 \mathrm{mM}$ (Figure 2). This reflects that the production of carbohydrate from TCL-1 is inhibited at low feeding DIC concentrations, such as $28 \mathrm{mM}$, without nitrogen limitation. However, the carbohydrate content remains at about 25\% when the DIC concentration is over $57 \mathrm{mM}$. This reflects that no variations occur without $\mathrm{C}$ - and $\mathrm{N}$-limitation between
57 and $113 \mathrm{mM}$ of feeding DIC concentration. As for the carbohydrate productivity shown in Table 1 , the maximal level, about $150 \mathrm{mg} \mathrm{L}^{-1} \mathrm{~d}^{-1}$, can be obtained at the feeding DIC concentration of 85 or $113 \mathrm{mM}$ when the dilution rate is $0.036 \mathrm{~h}^{-1}$. In fact, this carbohydrate productivity is low compared with that found in other studies. For example, the maximal exopolysaccharide (EPS) productivity of a heterocystous cyanobacterium, Anabaena sp. ATCC 33047, is $1.1 \mathrm{~g} \mathrm{~L}^{-1} \mathrm{~d}^{-1}$ at an optimal condition [3]. The EPS from our species should be also analyzed to confirm the carbohydrate in the liquid phase. In addition, the optimal cultivated conditions must be defined for carbohydrate production if carbohydrate is the preferred product.

As shown in Figure 2, the protein content increases from 22 to $37 \%$ as the feeding DIC concentration increases from 28 to 85 or $113 \mathrm{mM}$. This indicates that protein synthesis is limited by carbon rather than nitrogen as the feeding DIC concentration is less than $58 \mathrm{mM}$. The maximal protein productivity of about $240 \mathrm{mg} \mathrm{L}^{-1} \mathrm{~d}^{-1}$ is obtained at the feeding DIC concentration of 85 or $113 \mathrm{mM}$. It is noted that protein may be applied to the food supply; however, it is probably a disadvantage for fuel production. For example, fuel- $\mathrm{NO}_{X}$ might be formed via combustion of biomass, or reduction components such as $\mathrm{HCN}$ and $\mathrm{NH}_{3}$ might be produced via pyrolysis of biomass [20]. Therefore, low $\mathrm{N}$ containing biomass is preferred for the biofuel aspect.

\subsection{Batch Cultivation under Various Initial DIN Concen-} trations. Since the cellular components are dependent on microbial species and the distribution between lipid and carbohydrates content is different even under the same Nlimiting conditions for different species, the content and productivity of cellular components of TCL-1 are valuable to be quantified as a function of initial dissolved inorganic nitrogen (DIN) (nitrate) concentrations and initial DIC concentrations.

Regarding the results of the continuous culture mentioned above, the maximal content of carbohydrate was found to be $25 \%$, and the lipid content was $28 \%$ while the nitrogen was not limited in the continuous culture. Further, it was of interest to find variations in cell mass and cellular components such as lipids and carbohydrates, as well as protein with $\mathrm{N}$-limitations in batch cultivation, and hence the cultivation of TCL-1 under various initial DIN 
TABLE 2: Cellular data for TCL-1 in a batch culture with various initial DIN concentrations $(N=3)$.

\begin{tabular}{|c|c|c|c|c|c|c|c|c|c|}
\hline \multirow[t]{2}{*}{ Item } & \multirow{2}{*}{$\begin{array}{c}\text { DIC con- } \\
\text { centration } \\
(\mathrm{mM}) \\
\text { Initial }\end{array}$} & \multicolumn{2}{|c|}{$\begin{array}{l}\text { DIN concentration } \\
(\mathrm{mM})\end{array}$} & \multirow[t]{2}{*}{$\mu^{\mathrm{a}}\left(\mathrm{d}^{-1}\right)$} & \multirow[t]{2}{*}{$\begin{array}{l}\mathrm{C} / \mathrm{N}^{\mathrm{d}}: \\
\text { Initial }\left(\text { Final }^{\mathrm{e}}\right)\end{array}$} & \multicolumn{4}{|c|}{$\begin{array}{l}\text { Maximum cell mass or cellular component mass } \\
\qquad\left(\mathrm{mg} \mathrm{L}^{-1}\right)\end{array}$} \\
\hline & & Initial & Final & & & Cell & Lipid & Carbohydrate & Protein \\
\hline 1 & 28 & 5.8 & 1.02 & $2.82 \pm 0.08$ & $4.8(5.1)$ & $701 \pm 2.0$ & 146 & 110 & 237 \\
\hline 2 & 57 & 5.8 & 0.18 & 3.00 & $8.1(1.3)$ & 1,106 & 254 & 506 & 136 \\
\hline 3 & 28 & 1.9 & 0.24 & $2.43 \pm 0.29$ & $14.7(54)$ & $567 \pm 39$ & 103 & 166 & 190 \\
\hline $4^{\mathrm{b}}$ & 28 & 0.6 & N.D. & $2.38 \pm 0.23$ & 46.7 (N.A.) $^{\mathrm{c}}$ & $192 \pm 25$ & 26 & 95 & 32 \\
\hline 5 & 57 & 0.6 & N.D. & 1.91 & 78.8 (N.A.) & 388 & 48 & 237 & 18 \\
\hline 6 & 28 & 0.2 & 0.09 & $2.36 \pm 0.11$ & 140 (152) & $85 \pm 6.9$ & 9 & 24 & 9 \\
\hline
\end{tabular}

${ }^{\mathrm{a}} \mu$ : specific growth rate; ${ }^{\mathrm{b}} \mathrm{N}=5 ;{ }^{\mathrm{c}} \mathrm{N}$.A.: not available due to the fact that the final DIN concentration is not detectable; ${ }^{\mathrm{d}} \mathrm{C} / \mathrm{N}$ : DIC concentration/DIN concentration, ${ }^{\mathrm{e}}$ Final: means the end of the $\log$ phase $\left(50^{\circ} \mathrm{C}\right.$ cultivation temperature, $10 \mathrm{klx}$ illumination intensity, and $28 \mathrm{mM}$ initial DIC concentration).

concentrations, as well as with $28 \mathrm{mM}$ or $57 \mathrm{mM}$ initial DIC concentrations in a batch culture, was conducted. As shown in Figure 3, the growth curves reveal that many different results under various initial DIN or DIC concentrations and higher cell densities could be obtained at higher initial DIN or DIC concentrations, resulting from the fact that there were enough materials for cell division (Table 2). Even though the maximal cell mass is extremely different with various initial DIN or DIC concentrations, the specific growth rates in the $\log$ phase are similar (between 2.4 and $3 \mathrm{~d}^{-1}$, Table 2). This indicated that TCL-1 has a high affinity for nitrate and cannot be inhibited significantly in the log phase under low DIN concentrations, even as low as $0.2 \mathrm{mM}$. However, the DIN concentration decreases with increases in the cell mass, resulting in extremely low final DIN concentrations, which in some cases was not even detectable. It is reasonable to assume that the flow of carbon fixed during photosynthesis switched from the protein synthesis pathway to form carbohydrates or accumulate lipids $[13,14]$.

In a previous study, Nitzschia sp. was cultivated with a medium of $10 \mathrm{mg} \mathrm{L}^{-1} \mathrm{NO}_{3}{ }^{-}-\mathrm{N}$, which was equivalent to about $0.71 \mathrm{mM}$ DIN, and $2.2 \mathrm{mg} \mathrm{L}^{-1} \mathrm{NO}_{3}^{-}{ }^{-} \mathrm{N}$ was removed within 15 days. The removal rate of $\mathrm{N}$ was $22 \%$ [21]. However, the final DIN was nondetectable within about 4 days as the initial DIN was $0.6 \mathrm{mM}$ with a DIC of either $28 \mathrm{mM}$ or $57 \mathrm{mM}$ as shown in items 4 and 5 of Table 2. The removal rate of $\mathrm{N}$ is about $60 \%$ for TCL-1. It seems that TCL- 1 has better ability to remove $\mathrm{N}$ than Nitzschia sp. Compared with the above results, an algal-bacterial biofilm exhibited a 70\% removal rate of $\mathrm{N}$ with the cultivation medium of $66 \pm 16 \mathrm{mg} \mathrm{L}^{-1} \mathrm{~N}$, which was equivalent to about $4.71 \mathrm{mM}$ DIN [22]. The $\mathrm{N}$-removal rate of TCL-1 was $82.4 \%$ and $96.9 \%$ within about 4 days with initial DIN of $5.8 \mathrm{mM}$ and a DIC of $28 \mathrm{mM}$ and $57 \mathrm{mM}$, as shown in items 1 and 2 of Table 2. In another previous study, Chlorella sorokiniana was cultivated with medium of $56 \mathrm{mg} \mathrm{L}^{-1} \mathrm{TN}$, which was equivalent to about $4 \mathrm{mM}$ DIN and $60.4 \% \mathrm{~N}$ and was removed within 20 days [23]. As shown in Figure 4, various maximum cell growth rate and DIN affinity constant were obtained by fitting as Monod-type equation under various initial DIC concentrations. The fitted maximum cell growth at $57 \mathrm{mM} \mathrm{DIC,} 3.21 \mathrm{~d}^{-1}$, is higher than that at $28 \mathrm{mM}$, $2.82 \mathrm{~d}^{-1}$. It seems to be carbon limitation condition at $28 \mathrm{mM}$

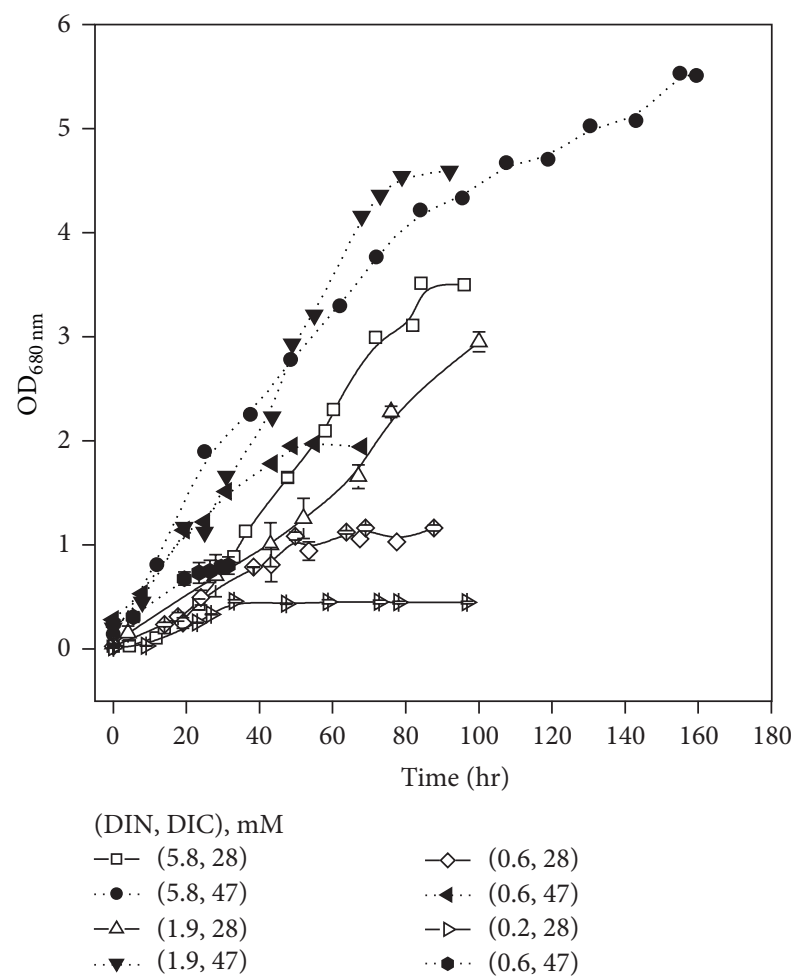

FIGURE 3: Growth curves under various DIC and DIN concentrations in a batch culture.

DIC in this study. Interestingly, the affinity constant at $28 \mathrm{mM}$ DIC, $0.12 \mathrm{mM}$, is much lower than that one at $57 \mathrm{mM}$ DIC, $0.41 \mathrm{mM}$. Consequently, TCL-1 may reveal higher affinity on DIN under more limited DIC conditions. Compared with the above values overall, TCL-1 has better ability to fix nitrogen than other microorganisms. TCL-1 is quite potential to treat the wastewater of environment for TCL-1 can grow and survive in a harsh environment with an extreme lack of nitrogen.

As shown in Figure 5, the carbohydrate content increases significantly from 16 to $50 \%$ as the initial DIN concentration decreases from 5.8 to $0.6 \mathrm{mM}$ at a $28 \mathrm{mM}$ DIC concentration, resulting in the flow of carbon fixed during photosynthesis being switched from the protein synthesis 


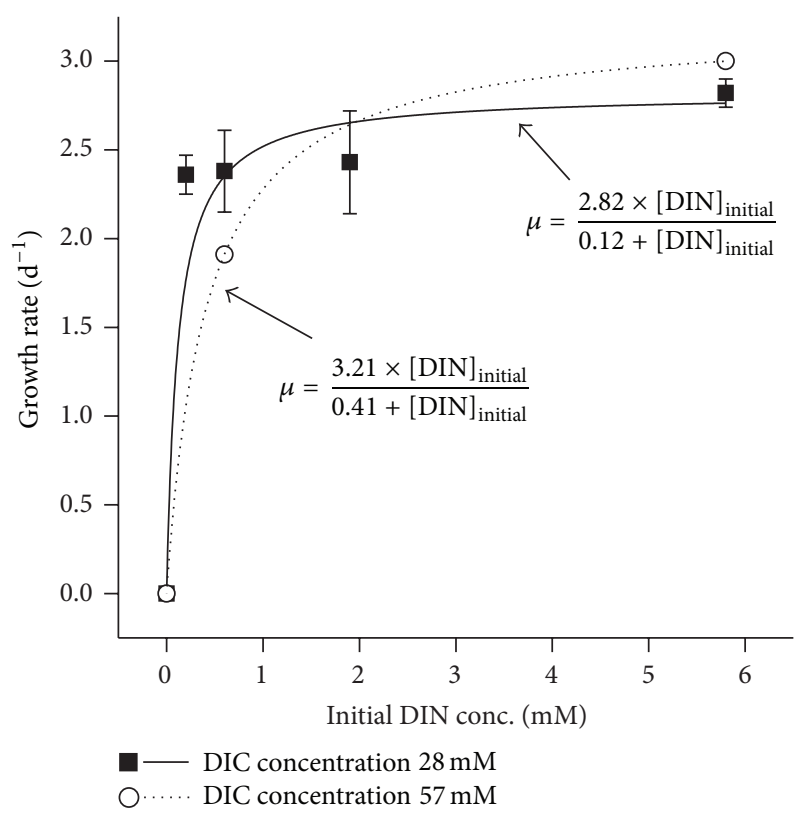

FIGURE 4: Monod-type equations under various DIC and DIN concentrations in a batch culture.

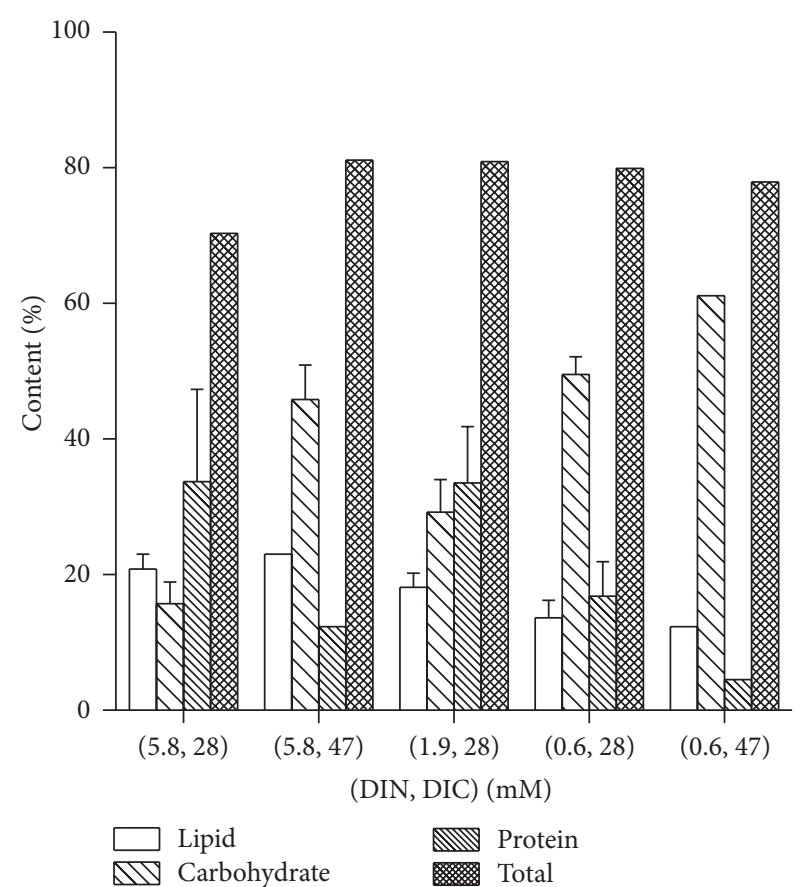

Figure 5: Cellular composition under various DIC and DIN concentrations in a batch culture.

path to the formation of carbohydrate [14]. Regarding the case of a $0.2 \mathrm{mM}$ initial DIN concentration, the cell growth time is so short that the cellular component is almost defined by the seeded cell; hence, no critical variations in the cellular component content could be observed. Since both carbohydrate acclimation and lipid acclimation are due to changes in the carbon flow resulting from protein synthesis, the effect of the concentration ratio of DIC/DIN for cell mass and cellular components should be emphasized. In Table 2, regarding the case of a $5.8 \mathrm{mM}$ initial DIN concentration, the maximal cell mass increases from 700 to $1,100 \mathrm{mg} \mathrm{L}^{-1}$ while the carbohydrate content increases from 16 to $46 \%$ as the initial DIC concentration increases from 28 to $47 \mathrm{mM}$. Similarly, the maximal cell mass increases from 192 to $388 \mathrm{mg} \mathrm{L}^{-1}$ while the carbohydrate content increases from 50 to $61 \%$ as the initial DIC concentration increases from 28 to $47 \mathrm{mM}$ from the initial DIN concentration of only $0.6 \mathrm{mM}$. These results indicate that not only maximal cell mass but also carbohydrate content is a function of the $\mathrm{C} / \mathrm{N}$ ratio at the same initial DIN concentrations. Actually, nitrate is depleted during the cultivation period, resulting in a significant increase in the $\mathrm{C} / \mathrm{N}$ ratio, except for the case of a $5.8 \mathrm{mM}$ initial DIN concentration (Table 2). Additionally, the residual DIC concentrations are all above $10 \mathrm{mM}$ when the initial DIN concentrations range from 0.2 to $1.9 \mathrm{mM}$. However, there is only a $5 \mathrm{mM}$ residual DIC concentration while the initial DIN concentration is $1.02 \mathrm{mM}$ and the initial DIN concentration is $5.8 \mathrm{mM}$, resulting in only $16 \%$ carbohydrate (Figure 5). When the initial DIC concentration increases from 28 to $47 \mathrm{mM}$, the residual DIN concentration is only $0.18 \mathrm{mM}$, resulting in a much higher carbohydrate content (46\%). As shown in Figure 5, the residual DIN concentration is $0.24 \mathrm{mM}$ in the case where the initial one is $1.9 \mathrm{mM}$. In this case, the carbohydrate content is $30 \%$, almost twofold of the case at $5.8 \mathrm{mM}$ initial DIN and $28 \mathrm{mM}$ initial DIC. When the residual DIN is not detectable as in the case of $0.6 \mathrm{mM}$ DIN and $28 \mathrm{mM}$ DIC, higher carbohydrate content, about $50 \%$, is obtained. Further, when the initial DIC concentration increases from 28 to $47 \mathrm{mM}$ at the same initial DIN concentration, $61 \%$ carbohydrate content is obtained (Figure 5). This indicates that the higher residual $\mathrm{C} / \mathrm{N}$ ratio in the case of a $47 \mathrm{mM}$ DIC is lower than that of the $28 \mathrm{mM}$ DIC even though the residual DIN concentrations are "not detectable." Consequently, cell mass and cellular composition depend on not only limited $\mathrm{N}$ concentrations but also the $\mathrm{C} / \mathrm{N}$ ratio.

Obviously, the flow of carbon fixed during photosynthesis switched from the protein synthesis pathway to forming carbohydrate under $\mathrm{N}$-limitation and a high $\mathrm{C} / \mathrm{N}$ ratio, as mentioned above. Further, it is of interest to see the variations in lipid content under various DIC and DIN concentrations in a batch culture. In addition, the lipid content decreases from 21 to $12 \%$ as the initial DIN concentration decreases from 5.8 to $0.6 \mathrm{mM}$, and this result indicates that the lipid content is limited under $\mathrm{N}$-limitation. For comparison of various initial DIC concentrations, 28 and $47 \mathrm{mM}$, the lipid content of TCL1 is almost the same as that in both the $5.8 \mathrm{mM}$ and $0.6 \mathrm{mM}$ initial DIN concentrations. In regard to these similar results, the lipid content decreases from 20 to $14 \%$ as the initial DIC concentration increases from 5 to $94 \mathrm{mM}$, resulting from the fact that the DIN concentration is lower as the initial DIC concentration becomes higher in the final stage of growth [1]. Consequently, the lipid synthesis of TCL-1 should be susceptible and limited under N-limitation.

Since, as indicated above, the flow of carbon fixed during photosynthesis switched from the protein synthesis pathway to forming carbohydrate under $\mathrm{N}$-limitation and a high 
TABLE 3: The comparison of performance between this study and other references.

\begin{tabular}{|c|c|c|c|c|c|c|}
\hline Species & Cultivation type & Conditions & Target & Productivity/removal effect & Unit & Reference \\
\hline Chlorella sp. & Semicontinuous & N-limitation & Lipid & 139 & $\mathrm{mg} \mathrm{d}^{-1} \mathrm{~L}^{-1}$ & [13] \\
\hline TCL-1 & Continuous & $0.036 \mathrm{~h}^{-1}$ & Lipid & 150 & $\mathrm{mg} \mathrm{d}^{-1} \mathrm{~L}^{-1}$ & This study \\
\hline Anabaena sp. & Continuous & $0.03 \mathrm{~h}^{-1}$ & EPS & 1100 & $\mathrm{mg} \mathrm{d}^{-1} \mathrm{~L}^{-1}$ & [3] \\
\hline TCL-1 & Continuous & $0.036 \mathrm{~h}^{-1}$ & Carbohydrate & 150 & $\mathrm{mg} \mathrm{d}^{-1} \mathrm{~L}^{-1}$ & This study \\
\hline Nitzschia sp. & Batch & $0.71 \mathrm{mM}$ DIN & DIN & 22 & $\%$ & [21] \\
\hline TCL-1 & Batch & $0.6 \mathrm{mM}$ DIN & DIN & 60 & $\%$ & This study \\
\hline Algal-bacterial biofilm & Batch & $4.71 \mathrm{mM}$ DIN & DIN & 70 & $\%$ & [22] \\
\hline TCL-1 & Batch & $5.8 \mathrm{mM}$ DIN & DIN & 96.9 & $\%$ & This study \\
\hline Chlorella sp. & Batch & 4 mM DIN & DIN & 60.4 & $\%$ & [23] \\
\hline
\end{tabular}

$\mathrm{C} / \mathrm{N}$ ratio for TCL-1, the protein content should be changed obviously in the present study. Indeed, as shown in Figure 5, the protein content is much lower when the initial DIC concentration is higher, resulting from the fact that the final DIN concentration is significantly different. For example, the protein content decreases from 34 to $12 \%$ as the DIC concentration increases from 28 to $47 \mathrm{mM}$ while the final DIN concentration decreases from 1 to $0.2 \mathrm{mM}$. Consequently, the flow of carbon fixed during photosynthesis switches from the protein synthesis pathway to forming carbohydrate and limiting lipid-synthesizing enzymes under $\mathrm{N}$-limitation and a high $\mathrm{C} / \mathrm{N}$ ratio for TCL-1, resulting in the acclimation of carbohydrates and a decrease in lipids and protein.

In order to compare the performance of this study and other studies we discussed in more clarity, the comparable information was summarized and listed in Table 3.

\section{Conclusions}

The results in the present study provide valuable information for biofuel production via biofixation of $\mathrm{CO}_{2}$ with a cyanobacterium, Thermosynechococcus sp. CL-1, under various carbon and nitrogen concentrations. High lipid productivity and $\mathrm{CO}_{2}$ uptake rate were obtained in the continuous cultivation. In addition, extra-high affinity on DIN (constant is $0.12 \mathrm{mM}$ ) under limited DIC conditions was obtained, and thus higher DIN removal efficiency is expected in the future application. Consequently, TCL-1 is an appropriate candidate to treat the wastewater of environment and produce the bioenergy precursors under extreme limited DIN conditions.

\section{Competing Interests}

The authors declare that there are no competing interests regarding the publication of this paper.

\section{Acknowledgments}

The authors gratefully acknowledge the National Science Council, Republic of China, for its financial support (NSC952218-E-006-019, NSC96-2218-E-006-295, and NSC96-EPAZ-110-001).

\section{References}

[1] H. T. Hsueh, W. J. Li, H. H. Chen, and H. Chu, "Carbon bio-fixation by photosynthesis of Thermosynechococcus sp. CL1 and Nannochloropsis oculta," Journal of Photochemistry and Photobiology B: Biology, vol. 95, no. 1, pp. 33-39, 2009.

[2] H. T. Hsueh, H. Chu, and S. T. Yu, "A batch study on the bio-fixation of carbon dioxide in the absorbed solution from a chemical wet scrubber by hot spring and marine algae," Chemosphere, vol. 66, no. 5, pp. 878-886, 2007.

[3] J. Moreno, M. A. Vargas, H. Olivares, J. Rivas, and M. G. Guerrero, "Exopolysaccharide production by the cyanobacterium Anabaena sp. ATCC 33047 in batch and continuous culture," Journal of Biotechnology, vol. 60, no. 3, pp. 175-182, 1998.

[4] J. F. Sánchez, J. M. Fernández-Sevilla, F. G. Acién, M. C. Cerón, J. Pérez-Parra, and E. Molina-Grima, "Biomass and lutein productivity of Scenedesmus almeriensis: influence of irradiance, dilution rate and temperature," Applied Microbiology and Biotechnology, vol. 79, no. 5, pp. 719-729, 2008.

[5] A. P. Carvalho and F. X. Malcata, "Effect of culture media on production of polyunsaturated fatty acids by Pavlova lutheri," Cryptogamie, Algologie, vol. 21, no. 1, pp. 59-71, 2000.

[6] L. A. Meireles, A. C. Guedes, and F. X. Malcata, "Increase of the yields of eicosapentaenoic and docosahexaenoic acids by the microalga Pavlova lutheri following random mutagenesis," Biotechnology and Bioengineering, vol. 81, no. 1, pp. 50-55, 2003.

[7] L. A. Meireles, A. C. Guedes, and F. X. Malcata, "Lipid class composition of the microalga Pavlova lutheri: eicosapentaenoic and docosahexaenoic acids," Journal of Agricultural and Food Chemistry, vol. 51, no. 8, pp. 2237-2241, 2003.

[8] A. P. Carvalho and F. X. Malcata, "Optimization of $\omega-3$ fatty acid production by microalgae: crossover effects of $\mathrm{CO}_{2}$ and light intensity under batch and continuous cultivation modes," Marine Biotechnology, vol. 7, no. 4, pp. 381-388, 2005.

[9] P. T. Vasudevan and M. Briggs, "Biodiesel production-current state of the art and challenges," Journal of Industrial Microbiology and Biotechnology, vol. 35, no. 5, pp. 421-430, 2008.

[10] C. E. Wyman, "Alternative fuels from biomass and their impact on carbon dioxide accumulation," Applied Biochemistry and Biotechnology, vol. 45-46, no. 1, pp. 897-915, 1994.

[11] H. T. Hsueh, H. Chu, and C. C. Chang, "Identification and characteristics of a cyanobacterium isolated from a hot spring with dissolved inorganic carbon," Environmental Science and Technology, vol. 41, no. 6, pp. 1909-1914, 2007.

[12] K. Yamaberi, M. Takagi, and T. Yoshida, "Nitrogen depletion for intracellular triglyceride accumulation to enhance liquefaction 
yield of marine microalgal cells into a fuel oil," Journal of Marine Biotechnology, vol. 6, no. 1, pp. 44-48, 1998.

[13] C.-H. Hsieh and W.-T. Wu, "Cultivation of microalgae for oil production with a cultivation strategy of urea limitation," Bioresource Technology, vol. 100, no. 17, pp. 3921-3926, 2009.

[14] F. M. L. D’Souza and G. J. Kelly, "Effects of a diet of a nitrogenlimited alga (Tetraselmis suecica) on growth, survival and biochemical composition of tiger prawn (Penaeus semisulcatus) larvae," Aquaculture, vol. 181, no. 3-4, pp. 311-329, 2000.

[15] M. M. Pacheco, M. Hoeltz, M. S. A. Moraes, and R. C. S. Schneider, "Microalgae: cultivation techniques and wastewater phycoremediation," Journal of Environmental Science and Health A, vol. 50, no. 6, pp. 585-601, 2015.

[16] T. Takeuchi, K. Utsunomiya, K. Kobayashi, M. Owada, and I. Karube, "Carbon dioxide fixation by a unicellular green alga Oocystis sp," Journal of Biotechnology, vol. 25, no. 3, pp. 261-267, 1992.

[17] O. Holm-Hansen, J. Coombs, B. E. Volcani, and P. M. Williams, "Quantitative micro-determination of lipid carbon in microorganisms," Analytical Biochemistry, vol. 19, no. 3, pp. 561-568, 1967.

[18] M. DuBois, K. A. Gilles, J. K. Hamilton, P. A. Rebers, and F. Smith, "Colorimetric method for determination of sugars and related substances," Analytical Chemistry, vol. 28, no. 3, pp. 350356, 1956.

[19] M. M. Bradford, "A rapid and sensitive method for the quantitation of microgram quantities of protein utilizing the principle of protein-dye binding," Analytical Biochemistry, vol. 72, no. 1-2, pp. 248-254, 1976.

[20] F.-J. Tian, J. Yu, L. J. McKenzie, J.-I. Hayashi, and C.-Z. Li, "Conversion of fuel-N into $\mathrm{HCN}$ and NH3 during the pyrolysis and gasification in steam: a comparative study of coal and biomass," Energy and Fuels, vol. 21, no. 2, pp. 517-521, 2007.

[21] N. C. Boelee, H. Temmink, M. Janssen, C. J. N. Buisman, and R. H. Wijffels, "Nitrogen and phosphorus removal from municipal wastewater effluent using microalgal biofilms," Water Research, vol. 45, no. 18, pp. 5925-5933, 2011.

[22] E. Posadas, P.-A. García-Encina, A. Soltau, A. Domínguez, I. Díaz, and R. Muñoz, "Carbon and nutrient removal from centrates and domestic wastewater using algal-bacterial biofilm bioreactors," Bioresource Technology, vol. 139, pp. 50-58, 2013.

[23] S. Zhang, C. Y. Lim, C.-L. Chen, H. Liu, and J.-Y. Wang, "Urban nutrient recovery from fresh human urine through cultivation of Chlorella sorokiniana," Journal of Environmental Management, vol. 145, pp. 129-136, 2014. 

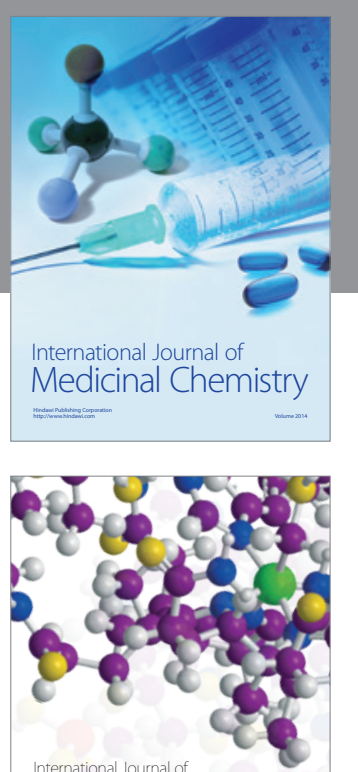

Carbohydrate Chemistry

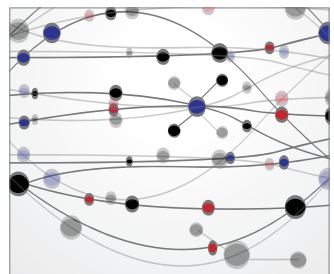

The Scientific World Journal
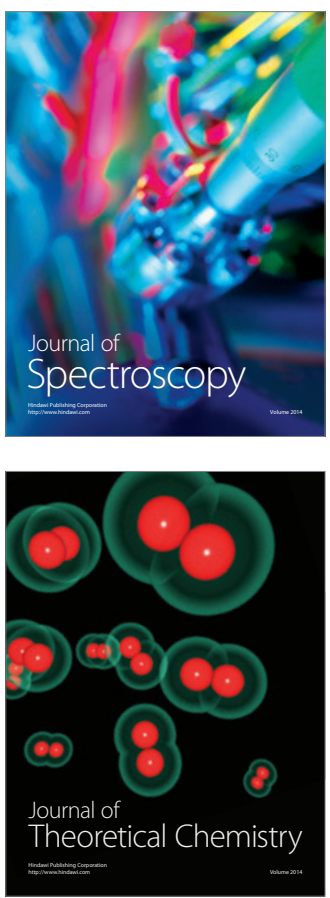
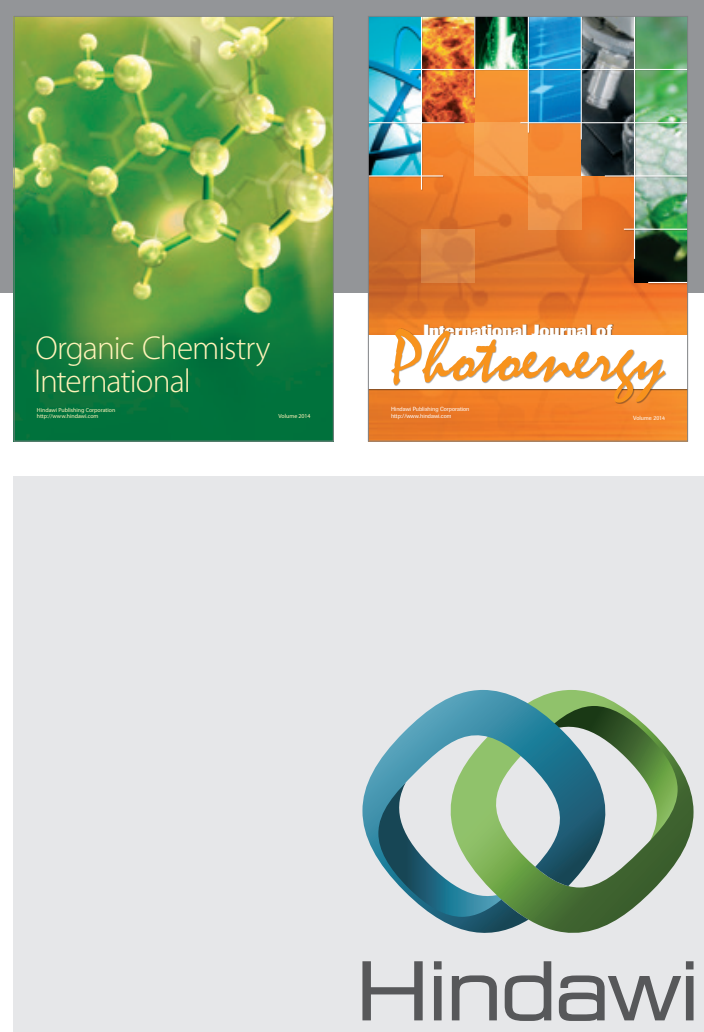

Submit your manuscripts at

http://www.hindawi.com

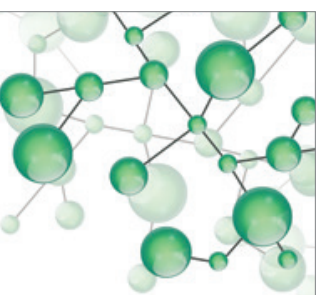

International Journal of

Inorganic Chemistry

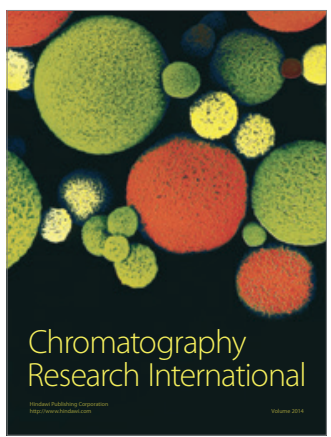

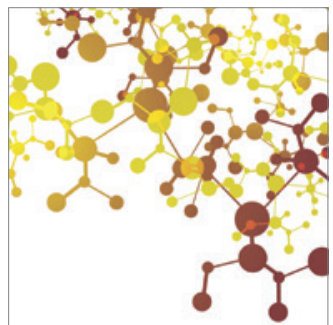

Applied Chemistry
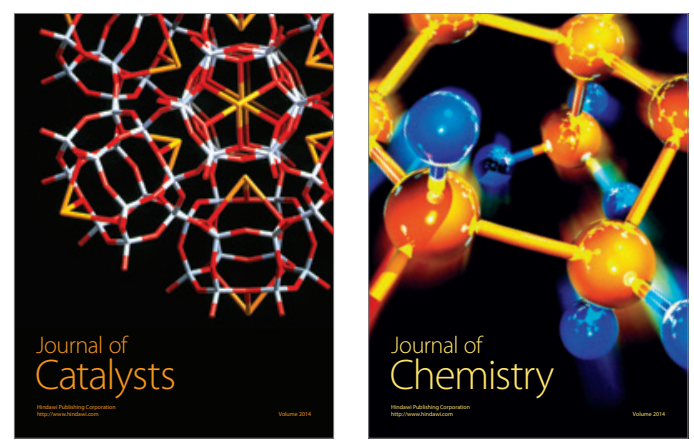
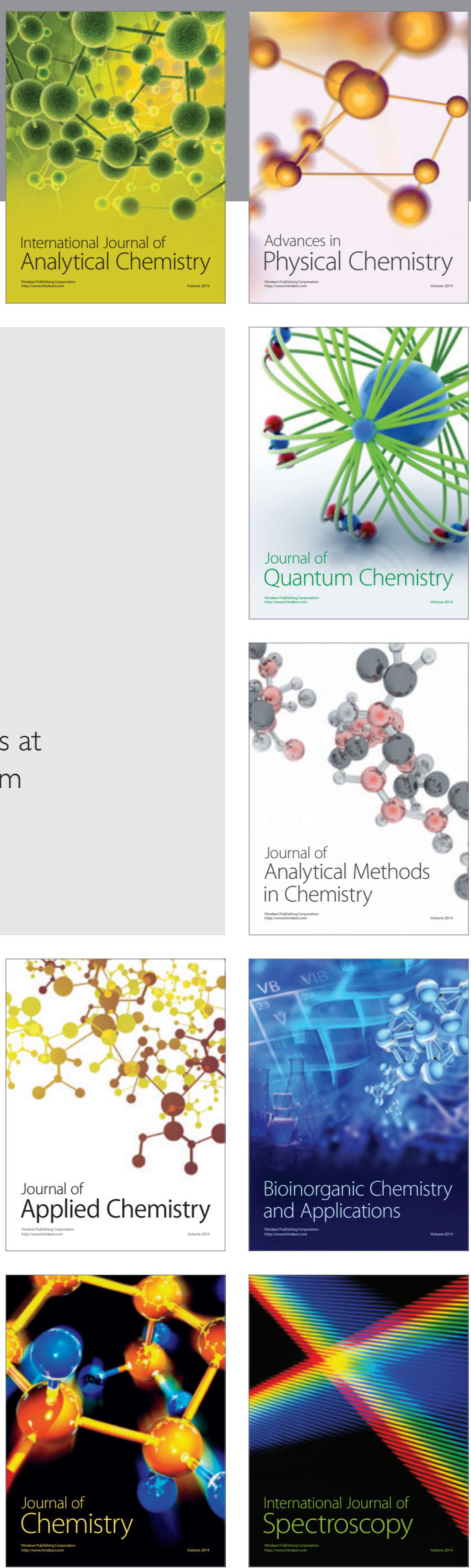